\title{
Chemical restraint of jaguars Panthera onca Linnaeus, 1758 with allometrically scaled doses of tiletamine, zolazepam, detomidine, and atropine
}

\author{
Contenção farmacológica de onças-pintadas Panthera onca \\ Linnaeus, 1758 com a associação de tiletamina, zolazepam, \\ detomidina e atropina calculados por extrapolação alométrica \\ interespecífica
}

\author{
Marcos Vinícius de Souza ${ }^{1 *}$; Liliane Rangel Nascimento ${ }^{2}$; \\ Líria Queiroz Luz Hirano3; \\ André Luiz Quagliatto Santos ${ }^{4}$; José Ricardo Pachaly ${ }^{5}$
}

\begin{abstract}
Chemical restraint of large felids is necessary for the handling, transportation, clinical assessment, and induction of anesthesia. The objective of this study was to evaluate the efficacy and safety of chemical restraint using a combination of tiletamine, zolazepam, detomidine, and atropine with interspecific allometric scaling doses in captive Panthera onca. There were ten males (two melanistic ones) and five females weighing between 35 and $80 \mathrm{~kg}$. The evaluation of the chemical restraint protocol was carried out during routine management of the animals for physical examination, collection of blood and bone marrow samples, dental evaluation, and other procedures. During pre-established intervals, rectal temperature, heart rate, respiratory rate, nociception of thoracic and pelvic limbs, muscle relaxation and loss of the righting reflex were monitored. Loss of the righting reflex occurred at $8 \pm 1.89$ minutes post-injection (MPI). Respiratory rate returned at 77.6 $\pm 8.18 \mathrm{MPI}$; return of consciousness occurred at $112.6 \pm 12.28 \mathrm{MPI}$, and complete recovery at $153 \pm 12.47 \mathrm{MPI}$. There were no statistical differences between heart and respiratory rate means and oxyhemoglobin saturation. For rectal temperature, there was a significant reduction. The protocol analyzed was efficient for the chemical restraint of jaguars, enabling the manipulation, transportation, physical examination, dental evaluation, blood and bone marrow sample collection, and other minor invasive procedures of medium duration in these animals. Key words: $\alpha_{2}$-adrenoceptor agonists. Allometry. Dissociative anesthetics. Felidae. Pantherinae.
\end{abstract}

\section{Resumo}

A contenção farmacológica de grandes felídeos é necessária para sua manipulação, transporte, avaliação clínica e indução anestésica. Por isso, objetivou-se avaliar a eficácia e a segurança da contenção

Prof., Faculdade do Futuro, FAF, Manhuaçu, MG, Brasil. E-mail: mvscardoso@yahoo.com.br

Discente de Doutorado, Universidade Federal de Uberlândia, UFU, Uberlândia, MG, Brasil. E-mail: albarreiro@uol.com.br

Profa, Universidade de Brasília, UnB, Brasília, DF, Brasil. E-mail: liriahirano@unb.br

Prof., UFU, Uberlândia, MG, Brasil. E-mail: quagliatto.andre@gmail.com

5 Prof., Universidade Paranaense, UNIPAR, Umuarana, PR, Brasil. E-mail: pachaly@uol.com.br

Author for correspondence 
farmacológica de exemplares de Panthera onca de cativeiro pela associação de tiletamina, zolazepam, detomidina e atropina, a partir de doses calculadas por meio de extrapolação alométrica interespecífica. Foram avaliados dez exemplares machos (dois melânicos) e cinco fêmeas, adultos, de Panthera onca. A contenção química foi realizada durante procedimentos de rotina dos animais para exame físico, colheita de sangue e medula óssea, avaliação odontológica e outros. Os parâmetros avaliados foram temperatura retal, frequências cardíaca e respiratória, nocicepção de membros torácicos e pélvicos, relaxamento muscular e reflexo de endireitamento. A perda da reação postural de endireitamento (RPE) ocorreu aos $8 \pm 1,89$ minutos pós-injeção (MPI). O retorno da RPE ocorreu em 77,6 $\pm 8,18$ MPI, o retorno das reações conscientes em 112,6 $\pm 12,28$ minutos e a recuperação total em $153 \pm 12,47$ MPI. Não foram encontradas diferenças estatísticas entre as médias de frequências cardíaca e respiratória e saturação parcial de oxiemoglobina. Em relação à temperatura retal, observou-se redução significativa. O protocolo avaliado foi eficiente para contenção farmacológica de todas as onças, viabilizando sua manipulação, transporte, exame físico, avaliação odontológica, colheita de sangue e medula óssea, e outros procedimentos pouco invasivos de média duração.

Palavras-chave: Agonistas alfa-2. Alometria. Anestésicos dissociativos. Felidae. Pantherinae.

\section{Introduction}

The jaguar (Panthera onca, Linnaeus, 1758 - Carnivora: Felidae) is the largest felid in the Americas and is only smaller than lions (Panthera leo) and tigers (Panthera tigris) (DEEM, 2004). Jaguars are classified as near threatened by the International Union for Conservation of Nature (IUCN), which makes their care in conservation breeding centers crucial even more important (QUIGLEY et al., 2017).

Chemical restraint of large felids is necessary for the handling, transportation, clinical assessment, and induction of anesthesia (CEREJO; MATTOS JÚNIOR, 2015). Despite the importance of determining efficient and safe protocols in clinical and surgical practice, most studies that cite the use of chemical restraint or anesthesia in jaguars involve few specimens or do not detail anesthesia monitoring or follow-up (AZEVEDO et al., 2008; BHARATHIDASAN et al., 2014; LIMA et al., 2012; McBRIDE JÚNIOR; McBRIDE, 2007; PIRES et al., 2010; SWANSON et al., 2003; TONIOLLO et al., 2000; WAELBERS et al., 2007; WIDMER, 2009).

Dissociative anesthetics and $\alpha_{2}$ agonists are the most commonly used drugs in chemical restraint of large felids (CEREJO; MATTOS JÚNIOR, 2015). Tiletamine hydrochloride is a potent dissociative anesthetic without muscle relaxation properties; because of this, it is commercially associated with zolazepam, a benzodiazepine anticonvulsant and muscle relaxant agent (DINIZ, 2011). These drugs show fast onset, and when they are associated with an $\alpha_{2}$-adrenoceptor agonist, such as detomidine, the effect is potentiated, and uneventful induction of anesthesia is possible (JACQUIER et al., 2006; LARICCHIUTA et al., 2015).

The use of atropine in anesthetic premedication is controversial due to its possible associated risks, such as increased arrhythmia occurrence, increased blood pressure and myocardial oxygen consumption (MAGOON et al., 1988). However, this anticholinergic drug is still widely used in veterinary dental procedures to reduce salivation, which may be induced by dissociative anesthesia with ketamine and tiletamine, and to reduce bradycardia induced by xylazine (BENGAZI et al., 2013; CESARETTI et al., 2018; NESGASH et al., 2016).

The objective of the present study was to evaluate efficiency and safety of allometrically scaled doses of a combination of tiletamine, zolazepam, detomidine, and atropine for chemical restraint of captive jaguars (Panthera onca).

\section{Material and Methods}

The study was approved by the Animal Research Ethics Committee of the Paranaense University 
(UNIPAR \#27332/2015). The animals evaluated in this study belonged to the NEX breeding facility (IBAMA \#232423), located in the city of Corumbá, Goiás, Brazil.

\section{Animals}

Fifteen adult jaguars were chemically restrained. The animals comprised 10 males (including two melanistic individuals) and five females weighing between 35 and $80 \mathrm{~kg}(57.34 \pm 12.66 \mathrm{~kg})$. Before being chemically restrained, each animal was submitted to fasting for 12 hours.
The protocol was carried out during the routine management of the animals for physical examination, collection of blood and bone marrow samples (Figure 1A), dental evaluation, and other necessary procedures. During the dental evaluation, it was observed that four males and one female needed urgent interventions (Figure 1B) and, because of that, restraint was prolonged with new administration of the same drug combination in doses that ranged from one third to a half of the initial dose, in order to enable periodontal, exodontic, endodontic, and restorative procedures.

Figure 1. Photos of captive Panthera onca individuals chemically restrained with a combination of tiletamine, zolazepam, detomidine, and atropine with doses calculated by means of interspecific allometric scaling. A - Collection of sternum bone marrow by means of aspiration with appropriate cannula. B - Assessment of the oral cavity for periodontal disease, coronal fractures in fangs with exposure of the dental pulp (white arrows), and tongue laceration (yellow arrow).

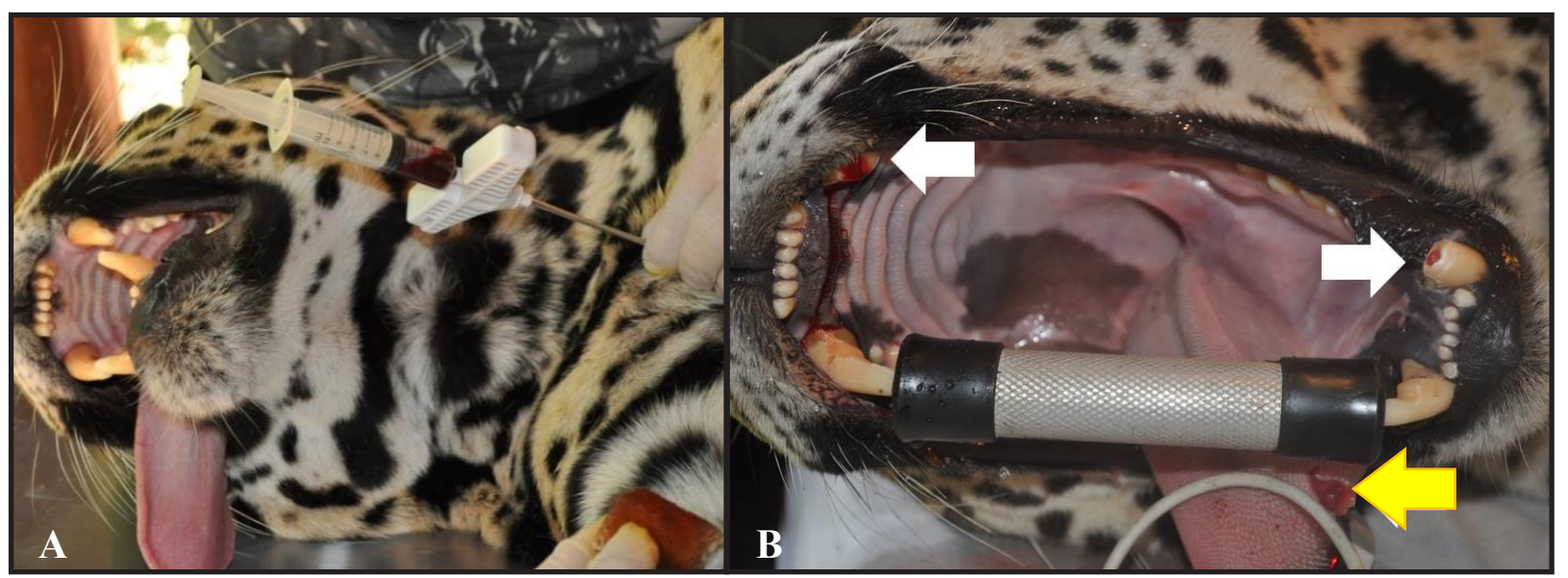

\section{Experimental design}

Doses were determined by means of interspecific allometric scaling, with basal metabolic rates (TMB) calculated by multiplying a proportionality constant (K, equal to 70 for Panthera onca) by the body mass $(\mathrm{M})$ of each animal in $\mathrm{kg}$ raised to 0.75 $\left(\mathrm{TMB}=\mathrm{K} \times \mathrm{M}^{0.75}\right.$ ) (FREITAS; CARREGARO, 2013; PACHALY, 2006). As jaguars represent a potential risk to human safety, their handling before chemical restraint was impossible, so archived data relating to the most recent record of body mass of each animal were used and, as soon as the animal could be handled after drug injection, each animal was weighed and, when necessary, the dose was adjusted.

The combination of tiletamine + zolazepam (Zoletil ${ }^{\circledR} 50$, Virbac do Brazil Indústria e Comércio Ltda, Jurubatuba, SP, Brazil), detomidine (Dormiun- $\mathrm{V}^{\circledR} 1 \%$, Agener União Saúde Animal, São Paulo, SP, Brazil), and atropine (Atropina 1\% 
Fagra $^{\circledR}$, Mairiporã, SO, Brazil) was administered by intramuscular injection (IM). For detomidine

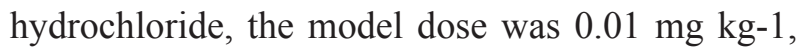
recommended for a 500-kg horse (HAMM et al., 1995); for atropine sulfate, $0.05 \mathrm{mg} \mathrm{kg}-1$ was used, as indicated for a 10-kg dog (UENO et al., 1999); for tiletamine + zolazepam, the model was $5.0 \mathrm{mg}$ kg-1 based on a 10-kg dog (JANG et al., 2015).

Dilution of Zoletil ${ }^{\circledR} 50$ was carried out by adding
$1.5 \mathrm{~mL}$ of sterile water to the flask containing the lyophilized compound to a final concentration of $166.6 \mathrm{mg} \mathrm{mL}-1$ of the tiletamine + zolazepam combination. Table 1 presents the volumes in $\mathrm{mL}$ of the drugs used in jaguars weighing from 35 to $80 \mathrm{~kg}$ calculated by means of allometric scaling. All animals received intravenous (IV) saline solution $0.9 \%$ at a $5 \mathrm{~mL} \mathrm{kg-1} \mathrm{h-1,} \mathrm{and} \mathrm{ophthalmic} \mathrm{ointment}$ (Epitezan $^{\circledR}$, Allergan Produtos Farmacêuticos Ltda, São Paulo, SP, Brazil).

Table 1. Doses in $\mathrm{mL}$ of the combination of Zoletil ${ }^{\circledR} 50$, Atropine $1 \%$, and Dormiun- $\mathrm{V}^{\circledR}$, calculated by means of interspecific allometric scaling indicated for intramuscular administration for chemical restraint of adult and sub-adult Panthera onca individuals weighing between 35 and $80 \mathrm{~kg}$.

\begin{tabular}{cccccccc}
\hline Weight & Zoletil $^{\circledR} \mathbf{5 0}$ & Dormiun- $^{\circledR}$ & Atropine & Weight & Zoletil $^{\circledR 50}{ }^{*}$ & Dormiun- $^{\circledR}$ & Atropine $^{\text {Dorm }}$ \\
\hline $\mathbf{3 5}$ & 0.77 & 0.14 & 0.13 & $\mathbf{5 8}$ & 1.12 & 0.20 & 0.19 \\
$\mathbf{3 6}$ & 0.78 & 0.14 & 0.13 & $\mathbf{5 9}$ & 1.14 & 0.20 & 0.19 \\
$\mathbf{3 7}$ & 0.80 & 0.14 & 0.13 & $\mathbf{6 0}$ & 1.15 & 0.20 & 0.19 \\
$\mathbf{3 8}$ & 0.82 & 0.14 & 0.14 & $\mathbf{6 1}$ & 1.16 & 0.21 & 0.19 \\
$\mathbf{3 9}$ & 0.83 & 0.15 & 0.14 & $\mathbf{6 2}$ & 1.18 & 0.21 & 0.20 \\
$\mathbf{4 0}$ & 0.85 & 0.15 & 0.14 & $\mathbf{6 3}$ & 1.19 & 0.21 & 0.20 \\
$\mathbf{4 1}$ & 0.86 & 0.15 & 0.14 & $\mathbf{6 4}$ & 1.21 & 0.21 & 0.20 \\
$\mathbf{4 2}$ & 0.88 & 0.16 & 0.15 & $\mathbf{6 5}$ & 1.22 & 0.22 & 0.20 \\
$\mathbf{4 3}$ & 0.90 & 0.16 & 0.15 & $\mathbf{6 6}$ & 1.24 & 0.22 & 0.21 \\
$\mathbf{4 4}$ & 0.91 & 0.16 & 0.15 & $\mathbf{6 7}$ & 1.25 & 0.22 & 0.21 \\
$\mathbf{4 5}$ & 0.93 & 0.16 & 0.15 & $\mathbf{6 8}$ & 1.26 & 0.22 & 0.21 \\
$\mathbf{4 6}$ & 0.94 & 0.17 & 0.16 & $\mathbf{6 9}$ & 1.28 & 0.23 & 0.21 \\
$\mathbf{4 7}$ & 0.96 & 0.17 & 0.16 & $\mathbf{7 0}$ & 1.29 & 0.23 & 0.22 \\
$\mathbf{4 8}$ & 0.97 & 0.17 & 0.16 & $\mathbf{7 1}$ & 1.31 & 0.23 & 0.22 \\
$\mathbf{4 9}$ & 0.99 & 0.18 & 0.16 & $\mathbf{7 2}$ & 1.32 & 0.23 & 0.22 \\
$\mathbf{5 0}$ & 1.00 & 0.18 & 0.17 & $\mathbf{7 3}$ & 1.33 & 0.24 & 0.22 \\
$\mathbf{5 1}$ & 1.02 & 0.18 & 0.17 & $\mathbf{7 4}$ & 1.35 & 0.24 & 0.22 \\
$\mathbf{5 2}$ & 1.03 & 0.18 & 0.17 & $\mathbf{7 5}$ & 1.36 & 0.24 & 0.23 \\
$\mathbf{5 3}$ & 1.05 & 0.19 & 0.17 & $\mathbf{7 6}$ & 1.37 & 0.24 & 0.23 \\
$\mathbf{5 4}$ & 1.06 & 0.19 & 0.18 & $\mathbf{7 7}$ & 1.39 & 0.25 & 0.23 \\
$\mathbf{5 5}$ & 1.08 & 0.19 & 0.18 & $\mathbf{7 8}$ & 1.40 & 0.25 & 0.23 \\
$\mathbf{5 6}$ & 1.09 & 0.19 & 0.18 & $\mathbf{7 9}$ & 1.41 & 0.25 & 0.24 \\
$\mathbf{5 7}$ & 1.11 & 0.20 & 0.18 & $\mathbf{8 0}$ & 1.43 & 0.25 & 0.24 \\
\hline
\end{tabular}

* Dilution of Zoletil ${ }^{\circledR} 50$ was carried out by adding $1.5 \mathrm{~mL}$ of sterile water. 


\section{Parameters evaluated}

The time of injection was recorded and the procedures carried out after that were recorded as minutes post-injection (MPI). Data recording began soon after loss of the righting reflex, and was carried out at 10-min intervals until the beginning of recovery of each animal. At recovery, each animal was placed in its respective enclosure and was monitored from a distance until complete recovery.

Physical examination was carried out immediately after loss of the righting reflex, including visual inspection of the skin, hydration level assessment, body condition score, mucous membrane color, and auscultation, percussion, and palpation of the thorax and abdomen. During the pre-established intervals, rectal temperature
(RT, in ${ }^{\circ} \mathrm{C}$ ) was assessed by means of a quickread rectal thermometer inserted 2 to $4 \mathrm{~cm}$ along the lateral wall of the rectum and held against the rectal wall until the thermometer measured a stable temperature reading (signaled by a single beep). Peripheral oxyhemoglobin saturation $\left(\mathrm{SpO}_{2}\right.$, in \%) was determined by placing the sensor of the portable pulse oximeter (MD300-A, IMF Tecnologia para Saúde LTDA, São Paulo, SP, Brazil) on the tongue of the animal until it measured a stable saturation (Figure 2A). Heart rate (HR) in beats per minute (bpm) was determined with a stethoscope (Figure 2B) placed between the left inter-rib space for one minute. Respiratory rate $\left(\mathrm{F}_{\mathrm{R}}\right)$, in breaths per minute (bpm), was assessed using both the stethoscope and direct observation for one minute of respiratory movements.

Figure 2. Monitoring of captive Panthera onca individuals chemically restrained with a combination of tiletamine, zolazepam, detomidine, and atropine with doses calculated by means of interspecific allometric scaling. A - Pulse oximeter sensor placed on the tongue of the animal for assessment of oxyhemoglobinsaturation. B - Thorax auscultation of a melanistic specimen.

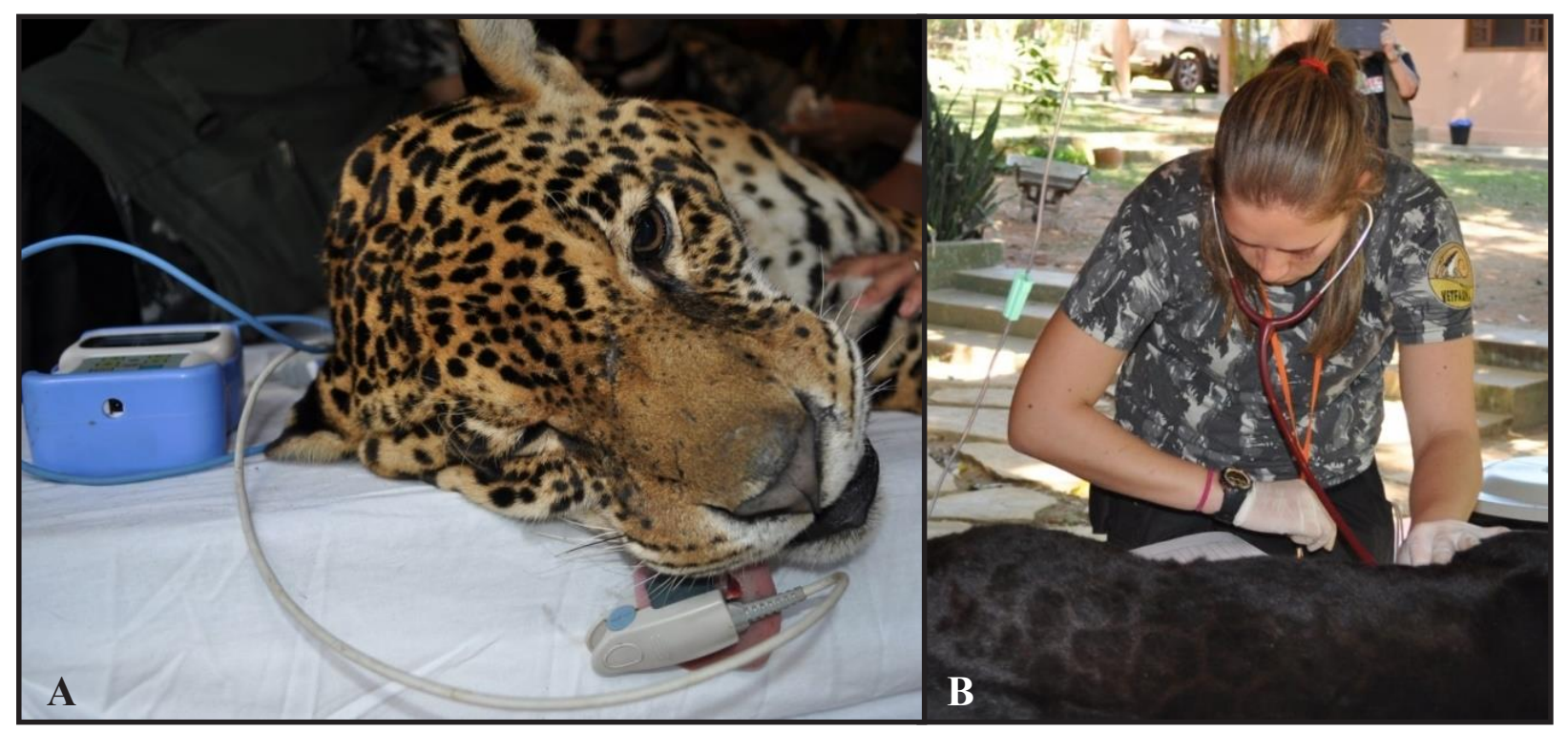

Nociception evaluation was carried out by pinching the second phalanx of one digit of the left thoracic and pelvic limbs with a hemostatic clamp, and muscle relaxation was monitored by the level of extensor muscle rigidity, resistance of the thoracic and pelvic limb to manipulation, and muscle tonus. These parameters were scored as 1, 2 or 3 according to the intensity and presence of a response (Table 2). 
Table 2. Score classification* of nociception and muscle relaxation evaluation of Panthera onca chemically-restrained with tiletamine, zolazepam, atropine, xylazine or detomidine

\begin{tabular}{llll}
\hline \multicolumn{1}{c}{ Parameter } & \multicolumn{1}{c}{ Score 1 } & \multicolumn{1}{c}{ Score 2 } & \multicolumn{1}{c}{ Score 3 } \\
\hline Nociception evaluation & $\begin{array}{l}\text { Intense painful reaction, } \\
\text { such as traction of the limb, } \\
\text { movements of the head, or } \\
\text { vocalization }\end{array}$ & $\begin{array}{l}\text { Moderate painful reaction } \\
\text { or discrete resistance to } \\
\text { the tests }\end{array}$ & Reaction absent \\
\hline Muscle relaxation & $\begin{array}{l}\text { Intense movement or cata- } \\
\text { lepsy }\end{array}$ & Moderate muscular tonus & $\begin{array}{l}\text { Muscle tonus absent with no } \\
\text { tremors and/or rigidity }\end{array}$ \\
\hline
\end{tabular}

*Adapted from Pachaly et al. (2014).

The lengths of the following intervals were recorded: time between drug administration and loss of the righting reflex; time between loss of the righting reflex and first attempt of the animal to move its head (conscious reaction); time until the righting reflex returned; and time until complete recovery, when jaguars walked normally.

\section{Statistical analysis}

Statistical analysis was performed with Biostat 5.0 software (UFPR, Curitiba - PR). The data are presented by means and standard deviation. The Shapiro-Wilk normality test was performed, then parameters with normal distribution were analyzed using the analysis of variance (ANOVA) and nonparametric parameters were analyzed with the Kruskal-Wallis test. A Spearman test was used to determine the presence of correlation between the monitored parameters and duration of the chemical restraint. Statistically significant intervals were analyzed by means of the Student-Newman-Keuls and Student tests. The significance level established was $5 \%$.

\section{Results}

During chemical restraint, one animal vomited and another was nauseated, without vomiting. None of the jaguars presented salivation or seizures during the procedures, and none of them died.

Among the vital parameters evaluated, heart rate, respiratory rate and rectal temperature showed significant correlations with time, with HR and RT decreasing with the duration of restraint progression of the records, and $\mathrm{F}_{\mathrm{R}}$ increasing with time. There were no statistical differences between the means of $\mathrm{HR}, \mathrm{F}_{\mathrm{R}}$, and $\mathrm{SpO}_{2}$. As for RT, there was a significant reduction from 40 MPI on, with means significantly lower than those observed in the first measurements, until the moment that the animals returned to their enclosures (Table 3).

Table 3. Mean and standard deviation of heart rate (HR, in beats per minute), respiratory rate $\left(\mathrm{F}_{\mathrm{R}}\right.$, in breaths per minute), rectal temperature (RT, in ${ }^{\circ} \mathrm{C}$ ) and oxyhemoglobins saturation $\left(\mathrm{SpO}_{2}\right.$, in \%) of Panthera onca chemically restrained with tiletamine, zolazepam, atropine, xylazine or detomidine.

\begin{tabular}{cccccc}
\hline MPI & $\mathbf{n}$ & HR & $\mathbf{F}_{\mathbf{R}}$ & $\mathbf{R T}$ & $\mathbf{S p O}_{2}$ \\
\hline 5 & 15 & $98.13 \pm 13.7$ & $18.46 \pm 5.3$ & $38.06 \pm 1.5$ & $94.71 \pm 2.5$ \\
10 & 15 & $95.14 \pm 12.4$ & $16.57 \pm 4.7$ & $38 \pm 0.6$ & $94.5 \pm 2.4$ \\
20 & 15 & $94.66 \pm 12.1$ & $16.57 \pm 2.6$ & $37.88 \pm 0.6$ & $88.8 \pm 7.8$
\end{tabular}


continuation

\begin{tabular}{cccccc}
30 & 15 & $90.93 \pm 11.1$ & $17.14 \pm 4.5$ & $37.59 \pm 0.7$ & $89.13 \pm 3.7$ \\
40 & 15 & $90 \pm 12$ & $18.93 \pm 5.3$ & $37.33 \pm 0.8$ & $90 \pm 5.1$ \\
50 & 15 & $87.43 \pm 10.3$ & $20.8 \pm 5.7$ & $37.11 \pm 0.8$ & $92.21 \pm 2.8$ \\
60 & 6 & $87.14 \pm 8.1$ & $21.6 \pm 5.8$ & $37.06 \pm 0.8$ & $89.93 \pm 4.4$ \\
70 & 6 & $88.28 \pm 11.6$ & $21.33 \pm 5.7$ & $37 \pm 0.8$ & $92.07 \pm 2.3$ \\
80 & 6 & $85.14 \pm 8.1$ & $20.27 \pm 5.9$ & $36.96 \pm 0.9$ & $89.53 \pm 4.9$ \\
90 & 6 & $86.57 \pm 9.1$ & $22.13 \pm 5.4$ & $36.94 \pm 0.8$ & $89.4 \pm 6.6$ \\
100 & 6 & $84.57 \pm 8.9$ & $21.86 \pm 6$ & $36.93 \pm 0.8$ & $90.73 \pm 3.5$ \\
110 & 5 & $85.53 \pm 9.5$ & $22.13 \pm 5.8$ & $36.9 \pm 0.9$ & $91.47 \pm 2.6$ \\
120 & 4 & $84.57 \pm 8.8$ & $22.93 \pm 5.7$ & $36.86 \pm 0.9$ & $91.57 \pm 2.3$ \\
130 & 3 & $84 \pm 9.5$ & $21.06 \pm 6.7$ & $36.86 \pm 0.9$ & $92.14 \pm 2.6$ \\
140 & 3 & $85.42 \pm 8.4$ & $21.86 \pm 6$ & $36.86 \pm 0.9$ & $92.2 \pm 2.4$ \\
150 & 3 & $85.42 \pm 9.1$ & $23.2 \pm 7.6$ & $36.82 \pm 1$ & $92 \pm 2.6$ \\
160 & 3 & $84.85 \pm 7.9$ & $21.86 \pm 6$ & $36.8 \pm 1$ & $91.53 \pm 3.1$ \\
170 & 3 & $84.28 \pm 8.2$ & $22.13 \pm 5.8$ & $36.79 \pm 1$ & $92.15 \pm 2.2$ \\
180 & 3 & $84.57 \pm 8.3$ & $22.13 \pm 6.1$ & $36.81 \pm 0.9$ & $91.86 \pm 2.1$ \\
190 & 3 & $85.14 \pm 7.6$ & $21.86 \pm 6$ & $36.76 \pm 1.2$ & $92.07 \pm 2.4$ \\
200 & 3 & $83.71 \pm 8.8$ & $22.13 \pm 5.8$ & $36.74 \pm 1.1$ & $91.6 \pm 2.3$ \\
210 & 1 & $84 \pm 9.1$ & $21.6 \pm 6.4$ & $36.76 \pm 1.1$ & $91.87 \pm 2.1$ \\
\hline
\end{tabular}

${ }^{a, b}$ : Standard deviations marked with the same letter in the same column are not significantly $(\mathrm{p}<0.05)$ different by the Student's $\mathrm{t}$ test.

MPI: minutes post injection

$\mathrm{n}$ : number of specimens evaluated.

As for nociceptive reactions, analgesia of the thoracic limb was considered excellent in $100 \%$ of the animals analyzed at $5 \mathrm{MPI}$, remaining like this for another 40 minutes. As for analgesia of the pelvic limb, at 5 MPI, 13 jaguars $(86.67 \%)$ showed an excellent response, with a total absence of reaction to pinching. Two other animals reached this state at 10 and 20 MPI. This antinociceptive effect in the pelvic limb lasted $41.66 \pm 8.29$ minutes on average.

All animals showed excellent muscle relaxation. Five minutes after the loss of the righting reflex, only one of the jaguars $(6.66 \%)$ showed good muscle relaxation, and the rest of the animals showed excellent relaxation for more than 40 minutes. The mandibular muscle relaxation pattern was not monitored in relation to time, but it was observed in all dental procedures, where animals showed complete relaxation of mandible muscles, lasting long enough for safe oral examination.
During induction, loss of the righting reflex occurred at $8 \pm 1.89 \mathrm{MPI}$. Return of the righting reflex occurred at $77.6 \pm 8.18 \mathrm{MPI}$; return of conscious reactions occurred at $112.6 \pm 12.28 \mathrm{MPI}$ and complete recovery occurred at $153 \pm 12.47 \mathrm{MPI}$.

\section{Discussion}

Although the indication of $\alpha_{2}$-adrenoceptor antagonists, pre-anesthetic drugs, is limited due to adverse effects observed mainly in combinations with $\alpha_{2}$-adrenoceptor agonists (FRANCO et al., 2009), they can be useful in situations involving potentially dangerous wild animals that do not allow good pre-anesthesia assessment. In the present study, the addition of the anticholinergic agent may have reduced sialorrhea, which made oral examination and dental procedures safer, and corroborates other veterinary dental research that 
used this combination (BENGAZI et al., 2013; CESARETTI et al., 2018; NESGASH et al., 2016). Excessive salivation is a dangerous occurrence during anesthesia, and it could result in liquid aspiration. Besides, there was no increase in heart rate, which probably maintained the consumption of oxygen by the myocardium at adequate levels.

In leopards and lions, the combination of ketamine and xylazine has led to intense salivation and to seizures (BELSARE; ATHREYA, 2010; EPSTEIN et al., 2002). These findings were not observed in the present study and in the study of Selmi et al. (2004) using tiletamine-zolazepamromifidine-atropine in Leopardus pardalis, as atropine controlled saliva secretion, and both zolazepam and romifidine or detomidine may have reduced the chances of seizures caused by tiletamine (LEWANDOWSKI et al., 2002). Control of the salivation and muscle contraction processes is advantageous, as it both increases the safety of handling the animals and makes dental evaluations and procedures easier.

In other studies, with a combination of tiletamine and zolazepam, smaller amounts of diluent were also used, or other drugs, such as detomidine and atropine, were used in the dilution in order to increase the concentration of the solution and decrease the volume of the final mixture (FAHLMAN et al., 2005; LIMA et al., 2012; OSILHIRI JÚNIOR et al., 2012; PACHALY; VOLTARELLI-PACHALY, 2011). In the present study, this technique enabled the use of a single dart in the administration of the restraint drugs, which made the process easier and reduced the stress for the animals.

The greater concentration of tiletamine + zolazepam is an important factor that enabled low volumes of detomidine in the protocol. Althought detomidine is largely used in equines, it has been evaluated in large felids with cardiopulmonary stability (ALBUQUERQUE et al., 2016; LARICCHIUTA et al., 2015), and its commercial concentration facilitates its use in heavy animals.
The $\alpha_{2}$-adrenoceptor agonists potentiate the action of dissociative anesthetics and, in the present study, this effect enabled a reduction of up to $75 \%$ of tiletamine + zolazepam when compared with other studies carried out with each of these drugs alone (GRASSMAN JÚNIOR et al., 2004; KREEGER et al., 2002; NÁJERA et al., 2013; SELMI et al., 2004).

A frequent finding in studies with chemical restraint and anesthesia in felids is hyperthermia, which occurs mainly due to the fact that the animals are not able to lose heat by breathing during the procedures (CURRO et al., 2004; FAHLMAN et al., 2005). In the present study, this change was not observed, as all animals showed significant decreases in RT, which was also observed by Johansson et al. (2013) and Selmi et al. (2004) who used tiletamine + zolazepam combined with medetomidine and romifidine, respectively, in large felids. Hypothermia observed in the present study was considered to be mild, since the mean temperature of the animals was above $36^{\circ} \mathrm{C}$, and it was not necessary warm them during recovery (SELMI et al., 2004; SHINDLE; TEWES, 2000). The drop in body temperature was probably caused by detomidine, since $\alpha_{2}$-adrenoceptor agonists affect central thermogenesis control (MADDEN et al., 2013).

Values of mean $\mathrm{SpO}_{2}$ above $88 \%$, similar to those of the present study, were demonstrated during the chemical restraint of lions with medetomidine associated with tiletamine + zolazepam, with a combination of butorphanol, azaperone, and medetomidine (FAHLMAN et al., 2005; SEMJONOV et al., 2017). Deem (2004) considered that measurements below $80 \%$ represent respiratory depression and inadequate blood oxygenation. Álamo et al. (2015) working with alpacas, Giroux et al. (2016) working with rats and Jin et al. (2015) working with pandas considered hypoxemia as values below $90 \%$ of oxyhemoglobin saturation, but $90 \%$ of oxyhemoglobin saturation is usually considered severe hypoxemia (BIGBY 
et al., 2017). In our study, this parameter was sometimes difficult to assess, which may have been due to the initial action of detomidine on the $\alpha_{1}$-adrenoceptor agonists, with consequent peripheral vasoconstriction, probably maintained by the later decrease in body temperature and/or the hypotension induced by detomidine ( $\mathrm{REICH}$ et al., 1996). In further studies, it is recommended that arterial blood gas evaluation should be used as a more accurate measure of oxygen saturation and oxygen supplementation (JOHANSSON et al., 2013)

In our study, we did not verify clinical changes in HR, and mean HR observed during monitoring was compatible with the 70 to $140 \mathrm{bpm}$ range considered normal for jaguars under chemical restraint (DEEM, 2004), which corroborates the data of Osilhiri Júnior et al. (2012) in free-living jaguars anesthetized with the same drug combination at a different dilution. The absence of bradycardia was an advantage observed in the present study and may have been the result of tiletamine action associated with the beneficial antimuscarinic effects promoted by atropine (CONGDON et al., 2011; LIN et al., 1993).

Loss of the righting reflex occurred at $8 \pm 1.89$ MPI, which is a shorter interval than that observed by Osilhiri Júnior et al. (2012) in free living jaguars restrained with a similar protocol. This result may be related to the lower level of stress of the animals before the chemical restraint, since the present study was based on captive animals, which are more conditioned to the presence of humans.

Selmi et al. (2004) used $3.5 \mathrm{mg} \mathrm{kg}-1$ tiletamine + zolazepam associated with romifidine and atropine in ocelots, and reported a mean latency period of 7 $\pm 4.5 \mathrm{~min}$, an interval close to the one obtained in jaguars. Additionally, these authors reported that at 52.3 minutes, the animals were already able to stand and walk short distances, an interval that is much shorter than the one recorded in jaguars. Although in ocelots romifidine was used, we emphasize the need to carry out studies on the determination of chemical restraint protocols specific for each wild felid species, since there is wide variation among the animals in this taxon.

\section{Conclusion}

The combination of tiletamine, zolazepam, detomidine, and atropine in doses calculated by means of interspecific allometric scaling was efficient and safe for the chemical restraint of 15 captive Panthera onca individuals.

The protocol evaluated in this study is indicated for procedures such as transportation, physical examination, blood and bone marrow sample collection, dental evaluation, and other minor invasive procedures lasting up to 50 minutes in jaguars. It may also be used as a form of preanesthetic medication in situations that demand complex and lengthy surgeries in these animals, enabling all necessary procedures for induction as well as for total intravenous or inhaled anesthesia.

\section{References}

ÁLAMO, A. M.; MANDSAGER, R. E.; RIEBOLD, T. W.; PAYTON, M. E. Evaluation of intravenous administration of alfaxalone, propofol, and ketaminediazepam for anesthesia in alpacas. Veterinary Anaesthesia and Analgesia, Oxford, v. 42, n. 1, p. 72-82, 2015.

ALBUQUERQUE, V. B.; ARAÚJO, M. A.; OLIVEIRA, A. R.; CAVALCANTI, G.; LEAL, R. C.; SANTOS, E. B.; CAVALCANTI, A. R.; FRAZILIO, F. O. Evaluation of cardiopulmonary parameters and recovery from anesthesia in cougars (Puma concolor) anesthetized with detomidine/ketamine and isoflurane or sevoflurane. Pesquisa Veterinária Brasileira, Rio de Janeiro, v. 36, n. 1, p. 33-38, 2016.

AZEVEDO, M. H. F.; PAULA, T. A. R.; BALARINI, M. K.; MATTA, S. L. P.; PEIXOTO, J. V.; LEITE, F. L. G.; ROSSI JÚNIOR, J. L.; COSTA, E. P. Organization and quantification of the elements in the intertubular space in the adult jaguar testis (Panthera onca, LINNAEUS, 1758). Micron, Oxford, v. 39, n. 2008, p. 1166-1170, 2008 . 
BELSARE, A. V.; ATHREYA, V. R. Use of xylazine hydrochloride-ketamine hydrochloride for immobilization of wild leopards (Panthera pardus fusca) in emergency situations. Journal of Zoo and Wildlife Medicine, Lawrence, v. 41, n. 2, p. 331-333, 2010.

BENGAZI, F.; LANG, N. K.; CAROPRESE, M.; VELEZ, J. U.; FAVERO, V.; BOTTICELLI, D. Dimensional changes in soft tissues around dental implants following free gingival grafting: an experimental study in dogs. Clinical Oral Implants Research, Copenhagen, v. 26, n. 2, p. 176-182, 2013.

BHARATHIDASAN, M.; THIRUMURUGAN, R.; WILLIAM, B. J.; GEORGE, R. S.; ARUNPRASAD, A.; KANNAN, T. A.; VIRAMUTHU, S. Xylazine-ketamine immobilization and propofol anesthesia for surgical excision of sebaceous adenoma in a jaguar (Panthera onca). Veterinary World, Bangkok, v. 7, n. 11, p. 986$990,2014$.

BIGBY, S. E.; BETHS, T.; BAUQUIER, S.; CARTER, J. E. Effect of rate of administration of propofol or alfaxalone on induction dose requirements and occurrence of apnea in dogs. Veterinary Anaesthesia and Analgesia, Oxford, v. 44, n. 6, p. 1267-1275, 2017.

CEREJO, A. S.; MATTOS JÚNIOR, E. Contenção farmacológica em felinos silvestres. Investigação, Franca, v. 14, n. 1, p. 39-65, 2015.

CESARETTI, C.; LANG, N. P.; VIGANÒ, P.; BENGAZI, F.; APAZA ALCCAYHUAMAN, K. A.; BOTTICELLI, D. Immediate and delayed loading of fixed dental prostheses supported by single or two splinted implants: A histomorphometric study in dogs. Journal of Oral Rehabilitation, Oxford, v. 45, n. 4, p. 308-316, 2018.

CONGDON, J. M.; MARQUEZ, M.; NIYOM, S.; BOSCAN, P. Evaluation of sedative and cardiovascular effects of intramuscular administration of dexmedetomidine with and without concurrent atropine administration in dogs. Journal of the American Veterinary Medical Association, Schaumburg, v. 239, n. 1, p. 81-88, 2011.

CURRO, T. G.; OKESON, D.; ZIMMERMAN, D.; ARMSTRONG, D. L.; SIMMONS, L. G. Xylazinemidazolam-ketamine versus medetomidine-midazolamketamine anesthesia in captive Siberian tigers (Panthera tigris altaica). Journal of Zoo and Wildlife Medicine, Lawrence, v. 35, n. 3, p. 320-327, 2004.

DEEM, S. L. Capture and immobilization of free-living Jaguars (Panthera onca). In: HEARD, D. Zoological restraint and anesthesia. Ithaca: International Veterinary Information Service, 2004. p. 1-13.
DINIZ, L. S. M. Imobilização química em animais selvagens. In: SPINOSA, H. S.; GÓRNIAK, S. L.; BERNANRDI, M. M. Farmacologia aplicada à medicina veterinária. Rio de Janeiro: Guanabara Koogan, 2011. p. 186-201.

EPSTEIN, A.; WHITE, R.; HOROWTIZ, I. H.; KASS, P. H.; OFRI, R. Effects of propofol as an anaesthetic agent in adult lions (Panthera leo): A comparison with two established protocols. Research in Veterinary Science, London, v. 72, n. 2, p. 137-140, 2002.

FAHLMAN, A.; LOVERIDGE, A.; WENHAM, C.; FOGGIN, C.; ARNEMO, J. M.; NYMAN, G. Reversible anaesthesia of free-ranging lions (Panthera leo) in Zimbabwe. Journal of the South African Veterinary Association, Petroria, v. 76, n. 4, p. 187-192, 2005.

FRANCO, L. G.; FIORAVANTI, M. C. S.; DAMASCENO, A. D.; BORGES, A. C.; SOARES, L. K.; RABELO, R. E.; SILVA, L. A. F. Assessment of serum enzymatic markers of cardiomyocytes injury in female dogs submitted to ketamine $\mathrm{S}(+)$, atropin and xylazine association. Acta Cirurgica Brasileira, São Paulo, v. 24, n. 1, p. $36-42,2009$.

FREITAS, G. C.; CARREGARO, A. B. Aplicabilidade da extrapolação alométrica em protocolos terapêuticos para animais selvagens. Ciência Rural, Santa Maria, v. 43, n. 2, p. 297-304, 2013.

GIROUX, M.; SANTAMARIA, R.; HÉLIE, P.; BURNS, P.; BEAUDRY, F.; VACHON, P. Physiological, pharmacokinetic and liver metabolism comparisons between 3-, 6-, 12- and 18-month-old male Sprague Dawley rats under ketamine-xylazine anesthesia. Experimental Animals, Tokyo, v. 65, n. 1, p. 63-65, 2016.

GRASSMAN JÚNIOR, L. I.; AUSTIN, S. C.; TEWES, M. E.; SILVY, N. J. Comparative immobilization of wild felids in Thailand. Journal of Wildlife Diseases, Lawrence, v. 40, n. 3, p. 575-578, 2004.

HAMM. D.; TURCHI, P.; JÖCHLE, W. Sedative and analgesic effects of detomidine and romifidine in horses. The Veterinary Record, London, v. 136, n. 13, p. 324327, 1995.

JACQUIER, M.; AARHAUG, P.; ARNEMO, J. M.; BAUER, H.; ENRIQUEZ, B. Reversible immobilization of free-ranging african lions (Panthera leo) with medetomidine-tiletamine-zolazepam and atipamezole. Journal of Wildlife Diseases, Lawrence, v. 42, n. 2, p. 432-436, 2006.

JANG, M.; PARK, S.; SON, W.; JO, S.; HWANG, H.; SEO, K.; LEE, I. Effect of tiletamine-zolazepam on the intraocular pressure of the dog. Veterinary Ophthalmology, Ames, v. 18, n. 6, p. 481-484, 2015. 
JIN, Y.; QIAO, Y.; LIU, X.; PU, T.; XU, H.; LIN, D. Immobilization of wild giant panda (Ailuropoda melanoleuca) with dexmedetomidine-tiletaminezolazepam. Veterinary Anaesthesia and Analgesia, Oxford, v. 143, n. 3, p. 333-337, 2016.

JOHANSSON, Ö.; MALMSTEN, J.; MISHRA, C.; LKHAGVAJAV, P.; McCARTHY, T. Reversible immobilization of free-ranging Snow Leopards (Panthera uncia) with a combination of medetomidine and tiletamine-zolazepam. Journal of Wildlife Diseases, Ames, v. 49, n. 2, p. 338-346, 2013.

KREEGER, T. J.; ARNEMO, J. M.; RAATH, J. P. Handbook of wildlife chemical immobilization. Colorado: Wildlife Pharmaceuticals, 2002. 448 p.

LARICCHIUTA, P.; MONTE, V. de; CAMPOLO, M.; GRANO, F.; CROVACE, A.; STAFFIERI, F. Immobilization of captive tigers (Panthera tigris) with a combination of tiletamine, zolazepam, and detomidine. Zoo Biology, New York, v. 34, n. 1, p. 40-45, 2015.

LEWANDOWSKI, A. H.; BONAR, C. J.; EVANS, S. E. Tiletamine-zolazepam, ketamine, and xylazine anesthesia of captive Cheetah (Acinonyx jubatus). Journal of Zoo and Wildlife Medicine, Lawrence, v. 33, n. 4, p. 332-336, 2002.

LIMA, D. C. V.; SIQUEIRA, D. B.; MOTA, R. A.; RAMEH-DE-ALBUQUERQUE, L. C.; SOUZA, D. S. Microbiologia de swabs retais e otológicos em carnívoros silvestres do zoológico do Parque Estadual de Dois Irmãos, Pernambuco. Pesquisa Veterinária Brasileira, Seropédica, v. 32, n. 2, p. 159-164, 2012.

LIN, H. C.; THURMON, J. C.; BENSON, G. J.; TRANQUILLI, W. J. Telazol - a review of its pharmacology and use in veterinary medicine. Journal of Veterinary Pharmacology and Therapeutics, Oxford, v. 16, n. 1, p. 383-418, 1993.

MADDEN, C. J.; TUPONE, D.; CANO, G.; SHAUN, F. $\alpha 2$ Adrenergic receptor-mediated inhibition of thermogenesis. Journal of Neuroscience, New York, v. 33, n. 5, p. 2017-2028, 2013.

MAGOON, K. E.; HSU, W. H.; HEMBROUGH, F. B. The influence of atropine on the cardiopulmonary effects of a xylazine-ketamine combination in dogs. Archives Internationales de Pharmacodynamie et de Thérapie, Gent, v. 293, p. 143-153, 1988.

McBRIDE JÚNIOR, R. T.; McBRIDE, R. T. Safe and selective capture technique for Jaguars in the Paraguayan chaco. The Southwestern Naturalist, Lubbock, v. 54, n. 4, p. $570-577,2007$.
NÁJERA，F.; CEDIEL-ALGOVIA，R.; HEARN，A.; ROSS, J.; DENCH, R.; ALCÁZAR, P.; SENTHIVEL, N.; De GASPAR, IÑAKI.; REVUELTA, L. Chemical immobilization of Bornean leopard cats (Prionailurus bengalensis borneoensis) with tiletamine and zolazepam under field conditions in Borneo. Thai Journal of Veterinary Medicine, Bangkok, v. 43, n. 3, p. 445-448, 2013.

NESGASH, A.; YAREGAL, B.; KINDU, T.; HAILU, E. Evalution of general anesthesia using xylazineketamine combination with and without diazipam for ovariohysterectomy in bitches. Journal of Veterinary Science \& Technology, Los Angeles, v. 7, n. 6, p. 1-6, 2016.

OSILHIRI JÚNIOR, J. A.; LEMOS, R. P.; HERRERA, D.; PALHARI NETO, C.; BELETTINI, S. T.; PACHALY, J. R. Novo método para contenção farmacológica e anestesia de campo em onças-pintadas (Panthera onca), empregando a fórmula "ZAD" (Zoletil/ $/ 50 \AA+$ Atropina + Dormiun-V®) - Relato preliminar. A Hora Veterinária, Porto Alegre, v. 32, n. 189, p. 54-59, 2012.

PACHALY, J. R. Terapêutica por extrapolação alométrica. In: CUBAS, Z. S.; SILVA, J. C. R.; CATÃO-DIAS, J. L. Tratado de animais selvagens - medicina veterinária. São Paulo: Roca, 2006. p. 1215-1223.

PACHALY, J. R.; MONTEIRO-FILHO, E. L. A.; WERNER, P. R.; GIOVANELLI, D. F.; CONTI, J. B. de; WOSIAKI, S. R.; BELETTINI, S. T.; VOLTARELLIPACHALY, E. M. Cetamina, xilazina e atropina, em doses calculadas por extrapolação alométrica interespecífica, para contenção farmacológica da cutia (Dasyprocta azarae). Arquivos de Ciências Veterinárias e Zoologia da UNIPAR, Umuarama, v. 17, n. 1, p. 11-26, 2014.

PACHALY, J. R.; VOLTARELLI-PACHALY, E. M. Novo método para contenção farmacológica e anestesia de campo em leões (Panthera leo), empregando a fórmula "ZAD" (Zoletil/100 + Atropina + Dormiun-V) Relato preliminar. A Hora Veterinária, Porto Alegre, v. 31, n. 181, p. 75-80, 2011.

PIRES, M. V. M.; CASTRO, J. L. C.; BALTHAZAR, D. A.; WAJNBERG, R.; FEDULLO, L. P.; NEVES, C. P. Anestesia peridural contínua em onça-pintada (Panthera onca) submetida à mastectomia bilateral: relato de caso. Revista Eletrônica Novo Enfoque, Rio de Janeiro, v. 9, n. 9, p. 27-28, 2010.

QUIGLEY, H.; FOSTER, R.; PETRACCA, L.; PAYAN, E.; SALOM, R.; HARMSEN, B. 2017. Panthera onca (Linnaeus, 1758). The IUCN Red List of Threatened Species 2017: e.T15953A50658693. 2017. Available at: <http://dx.doi.org/10.2305/IUCN.UK.2017-3.RLTS. T15953A50658693.en>. Accessed at: 05 june 2018. 
REICH, D. L.; TIMCENKO, A.; BODIAN, C. A.; KRAIDIN, J.; HOFMAN, J.; DEPERIO, M.; KONSTADT, S. N.; KURKI, T.; EISENKRAFT, J. B. Predictors of pulse oximetry data failure. Anesthesiology, New York, v. 84, n. 1, p. 859-864, 1996.

SELMI, A. L.; FIGUEIREDO, J. P.; MENDES, G. M.; LINS, B. T. Effects of tiletamine/zolazepam-romifidineatropine in ocelots (Leopardus pardalis). Veterinary Anaesthesia and Analgesia, Ames, v. 31, n. 3, p. 222226, 2004.

SEMJONOV, A.; ANDRIANOV, V.; RAATH, J. P.; ORRO, T.; VENTER, D.; LAUBSCHER, L.; PFITZER, S. Evaluation of BAM (butorphanol-azaperonemedetomidine) in captive African lion (Panthera leo) immobilization. Veterinary Anaesthesia and Analgesia, Ames, v. S1467-2987, n. 17, p. 30064-30068, 2017.

SHINDLE, D. B.; TEWES, M. E. Immobilization of wild ocelots with tiletamine and zolazepam in southern Texas. Journal of Wildlife Diseases, Ames, v. 36, n. 3, p. 546$550,2000$.

SWANSON, W. F.; JOHNSON, W. E.; CAMBRE, R. C.; CITINO, S. B.; QUIGLEY, K. B.; BROUSSET, D. M. Reproductive status of endemic felid species in Latin
American zoos and implications for ex situ conservation. Zoo Biology, New York, v. 22, n. 5, p. 421-441, 2003.

TONIOLLO, G. H.; FARIA JÚNIOR, D.; LEGA, E.; BATISTA, C. M.; NUNES, N. Piômetra na espécie felina - relato de um caso em Panthera onca. Brazilian Journal of Veterinary Research and Animal Science, São Paulo, v. 37, n. 2, p. 166-168, 2000.

UENO, H.; YAMADA, H.; TANAKA, I.; KABA, N.; MATSUURA, M.; OKUMURA, M.; KADOSAWA, T.; FUJINAGA, T. Accelerating effects of chitosan for healing at early phase of experimental open wound in dogs. Biomaterials, Bhat, v. 20, n. 15, p. 1407-1414, 1999.

WAELBERS, T.; BOSMANS, T.; RISSELADA, M.; VERLEYEN, P.; POLIS, I. Inhalation anesthesia with isoflurane in a black jaguar (Panthera onca) for surgical repair of a fractured mandible. Vlaams Diergeneeskundig Tijdschrift, Ghent, v. 76, n. 2, p. 138-145, 2007.

WIDMER, C. E. Perfil sanitário de Onças-Pintadas (Panthera onca) de vida livre no Pantanal Sul do Mato Grosso do Sul - Brasil. 2009. Dissertação (Mestrado em Epidemiologia Experimental Aplica às Zoonoses) - Faculdade de Medicina Veterinária e Zootecnia, Universidade de São Paulo, São Paulo. 